\title{
DEVELOPMENT OF LASER WELDING SYSTEM FOR SIDE PANELS BY USING Digital MANufacturing TeChNOLOGY
}

\author{
PARK, H.-S.
}

Abstract: Nowadays, the increasing global competition forces manufacturing enterprises to apply new technologies such as laser welding to manufacturing of their products. In case of automotive industries, they interest in assembly system for BIW(Body In White) carrying out laser welding. In this paper, the method of implementation for digital laser welding assembly system is proposed. Based on the requirements of assembly tasks obtained through product analysis, process modeling is executed using the IDEFO and UML model. For digital assembly system, the selected components are modeled by using $3 D$ CAD tools. According to the system configuration strategy, lots of the alternative solutions for the assembly system for welding side panels are generated. Finally, the optimal laser welding system is chosen by the evaluation of the alternative solutions with TOPSIS(Technique for Order Preference by Similarity to Ideal Solution) method.

Key words: Digital manufacturing, Laser welding system, Structure planning, TOPSIS method.
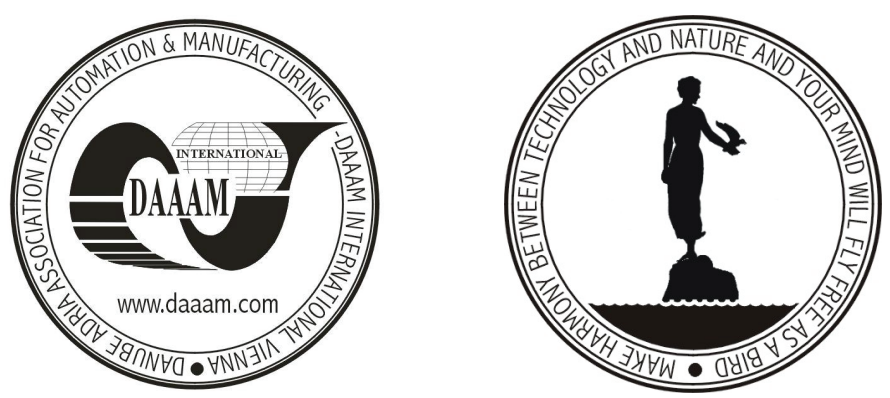

Authors' data: Prof. Dr. -Ing. Park H.[ong] S.[eok], University of Ulsan, South Korea,phosk@ulsan.ac.kr

This Publication has to be referred as: Park H.-S. (2006.). Development of Laser Welding System for Side Panels by Using Digital Manufacturing Technology, Chapter 38 in DAAAM International Scientific Book 2006, B. Katalinic (Ed.), Published by DAAAM International, ISBN 3-901509-47-X, ISSN 1726-9687, Vienna, Austria

DOI: $10.2507 /$ daaam.scibook.2006.38 